"Chernyi lebed'" v beloi maske. Analiticheskii doklad NIU VSbE $k$ godovshchine pandemii COVID-19 (2021) / ed. by S. M. Plaksin, A. B. Zhulin and S. A. Farizova. Moscow, National Research University Higher School of Economics. 336 p. (In Russ.).

Chto takoe Koeffitsient Sharpa - Primery ispol'zovaniia, Normy znachenii [online] Stolf. Available at: https://stolf.today/koefficient-sharpa.html (accessed: 06.06.2021).

Submission date: 08.06.2021.

Костина Анна Владимировна - доктор философских наук, доктор культурологии, профессор, проректор по научной работе Московского гуманитарного университета, академик Международной академии наук (Инсбрук, Австрия). Адрес: 111395, Россия, г. Москва, ул. Юности, 5. Тел.: +7 (499) 374-75-95. Эл. адрес: Anna_Kostina@inbox.ru

Kostina Anna Vladimirovna, Doctor of Philosophy, Doctor of Culturology, Professor, ViceRector for Research, Moscow University for the Humanities; Member, International Academy of Sciences (Innsbruck, Austria). Postal address: 5, Yunosti St., Moscow, Russian Federation, 111395. Tel.: +7 (499) 374-75-95. E-mail: Anna_Kostina@inbox.ru

DOI: $10.17805 /$ zpu.2021.3.4

\title{
Религиозные аспекты современной парадигмы самотворчества
}

\author{
A. А. ГОРЕЛОВ \\ ИнСтИтУт ФИЛОСОФИИ РАН, \\ Т. А. ГОРЕЛОВА \\ МОСКОВСКИЙ ГУМАНИТАРНЫЙ УНИВЕРСИТЕТ
}

В статье рассмотрены современные холистические концепции самотворчества (СT), возникшие на основе кардинально противоположных религиозных моделей - синергийной антропологии как попытки расширения и осмысления духовной практики исихазма (С. С. Хоружий) и концепции интегральной духовности на основе дзэн-буддизма (К. Уилбер). Представлены базовые концепты обеих точек зрения: дух, энергия, синергия - в синергийной антропологии; Космос, холон, холархия - в концепции интегральной духовности. СT, представляемое как восхождение по Лестнице духа на основе духовной практики исихазма, - это дерзновенная попытка эксперимента над собой, которая показывает путь обретения смысла жизни. Возникающая на основе этой практики доктрина пытается преодолеть ее субъективность через выделение универсальных состояний и переживаний: смысл жизни - миссия к Предстоянию, истина - Любовь, которая позволяет стать «горячим» в своем отношении к миру, механизм - соединение человеческих энергий с энергией Божественной, реализация - обращение к глубинной способности человека - «творчеству творчества», творчеству второго порядка, Самотворчеству.

Концепция интегральной духовности представляет СТ как холархию актуализации, проходящую девять базовых уровней сознания человека и которая в конце концов приходит к безличности и небытийности, превращаясь в свою противоположность - само-деконструкцию человека. Подробно рассмотрены основные отличия СТ в двух типах духовных практик. 
Ключевые слова: самотворчество; духовность; синергия; холархия; православие; исихазм; дзэн-буддизм; С. С. Хоружий; К. Уилбер

Памяти глубокоуважаемого коллеги С. С. Хоружего посвящается.

\section{ВВЕАЕНИЕ}

Постмодернистская философия подводит итог объективистской парадигме 1 Просвещения, согласно которой существует, с одной стороны, эмпирический, чувственно-воспринимаемый мир, а с другой - субъект, человек, способный все более точно отражать эту реальность, приближая свое знание к «истине». Постмодернистская парадигма утверждает, что любое «видение» мира «сконструировано социально», т. е. зависит не только от самого наблюдателя в данный момент его существования, но и от исторического окружения и культурных детерминант. Иными словами, все мировоззрения произвольны, ценности, обусловленные культурой данного времени, относительны и нет никаких универсальных истин. Человек же обретает единственный статус - телесно-разумного существа, полностью утратившего надежду на вечность - и душевную, и духовную, которая поддерживала его на всех этапах эволюции культуры. Постмодернизм ввергает теперь уже глобальное человечество в такой кризис отсутствия подлинных целей и ценностей, которого оно ранее не знало.

С осевого времени в различных цивилизациях существовал духовный авангард, который прорывался к новизне и формулировал цели будущего. В Античности таким авангардом были философы, которые в качестве цели обозначили истину. В Средневековье телосом христианского авангарда стало предстояние перед $\Lambda$ иком Господа, в котором заключено все - и Истина, и Смысл. Возрожденческая апология Человека приводит к идее господства над природой, которая, в конце концов, заканчивается кризисом науки и тупиком постмодернистского философского релятивизма. Несмотря на общую депрессивность выводов, в постмодернизме присутствует глубоко позитивное открытие абсолютной новизны: каждая эпоха не только трактует мир как другой, но он и на самом деле является другим. Поэтому идея развития, и, в более конкретном виде, идея эволюции, становится внутренне присущей культуре. Отныне и человек - больше не наблюдатель со стороны, но органично связанная с миром его часть, причем сознание этой части способно творить себя и мир. Именно в силу этого выход из современного духовного кризиса включает категорический императив, но не кантовский императив долга, а императив возвышения духа, призывающий человека изменить себя и, в конце концов, мир.

Потребность самоизменения, самотворчества (СТ), проявившись в «осевое время», эволюционирует, углубляясь и последовательно изменяя формы и цели. Основа СТ имеет четыре базиса - онтологический, гносеологический, антропологический и социальный. Онтологическую основу составляет внутренняя духовная работа по осуществлению себя. Гносеологическая отражает возможность самопознания, открывания новизны в самом себе. Антропологическая составляющая предполагает уход от массовидности, отказ от das Man во имя Dasein (Хайдеггер, 1997). Социальный базис требует духовного преобразования общества потребления. Из истории следует, что во все времена - в Античности, Средневековье и позже - были люди, которые ощущали себя призванными к этой внутренней работе. 
Самосозидание, как и любое творчество, требует соединения цели жизни, реализуемой через триединство «творчество - поиск истины - поиск смысла», с изменением поведения и внутреннего образа жизни человека. В Античности попытка синтеза проявилась в открытой и явной форме через философию, которая свой смысл определила как поиск истины, а ее искателем назвала человека, готовящего себя к свободному творчеству через философскую «медицину души» - самоконтроль и «практику себя». Системы самоконтроля - духовные упражнения «научиться жить», «научиться общению с Аругим» и «научиться умирать» - различались в философских школах (см. Горелов, Горелова, 2020a, b). Античное «поле» самоизменения имело две «координаты» регуляции - тело и душу (разумность как высшее ее свойство относилась к душе). Способы регуляции, или «упражнения», касались всех областей жизнедеятельности и были двоякого типа - на ограничение и на развитие: ограничения для тела (в еде, питье, похоти и т. п.) и для его развития - гимнастика; ограничения для души (желаний и страстей) и для ее развития - самообладание, опирающееся на волю.

Попытка объединения накопленного на закате Античности воплотилась уже не в системе упражнений, а в холистической духовной практике неоплатоника Плотина - практике «восхождения в горний мир» (Горелов, Горелова, 2020с). Он первым в истории начал строить СТ как духовную практику в трехмерной системе координат - тело, душа, Единое (Благо). Аоктринальная цель Плотина - перешагнуть за рамки рационального поиска истины в широкую область Единого как Блага - осуществлялась через практику аскезы, доходящую у него до «отказа» от тела.

Но настоящим вызовом двухмерной, «плоскостной», картине человеческой жизни стало христианское представление о Аухе святом, а значит, и о наличии третьего измерения - духовного. Историческое размежевание христианства привело к тому, что в трех его ветвях принципы внутреннего строительства религии и цели ее авангарда стали различаться. «Роль высшего авторитета в католичестве принадлежит папе и курии, в протестантизме - теологам, а в православии - аскетам, людям мистического опыта и святой жизни» (Хоружий, 2000: 181). Конечно, мыслители-мистики были и в западном христианстве, но только византийское православие в лице исихазма породило «духовный феномен и духовный путь, не ограниченный... институциональными рамками, несущий в себе общезначимую универсальную стратегию человеческого самоосуществления» (там же: 232).

Революционный перелом нашего времени состоит в смене ракурса взгляда на мир: «Мы видим и знаем то, что полюбили и избрали, а то, от чего отпали, что отвергли, то перестаем видеть и знать. <...> Аля мира же иного, мира невидимых вещей, мы вновь должны совершить акт свободного волевого избрания... т. е. акт веры» (Бердяев, 1989а: 51). Новый ракурс требует новых источников философского вдохновения. Одним из таких источников стало «предрасположение к буддизму», возникшее из-за отказа от метафизики в пост-гегелевской философии XIX в., и появление принципиально новых направлений - философии воли А. Шопенгауэра и философии бессознательного Э. Гартмана, от которых «веет холодом буддийского пессимизма (Бернюкович, 2009: 32).

В разговор на тему «христианство - буддизм в доктринально-религиозном смысле» вступает и русская религиозная философия XIX-XX вв. В. С. Соловьев поновому переосмысливает идею всеединства; В. А. Кожевников называет буддизм «учением о спасении без спасителя» и фиксирует принципиальное отличие православной философии, которая обращается к сердцу, к чувству, от учения Гаутамы, 
обращенного к рассудку; С. Н. Булгаков пишет о положительном и божественном значении нирваны; Н. О. Аосский, с одной стороны, примеряет буддистскую теорию перевоплощения к новой христианской теодицее через карму как организующий әлемент, но с другой - показывает противоположность обожения человека его «растворению» в нирване; С. $\Lambda$. Франк рассматривает антагонизм христианской идеи «перевоплощения души» буддистской концепции «переселения душ» (там же: 34-48). Н. А. Бердяев видит крайности православия и буддизма в отношении к страданию: «Христианство принимает страдание, принимает крест и в просветленном перенесении страдания ищет освобождения и спасения. Буддизм не принимает мира, хочет победить желание, привязывающее к миру, и достигнуть нирваны, которая... лежит по ту сторону бытия и небытия, не есть ни существование, ни не-существование» (Бердяев, 1952: 94-95). Буддизм не стремится изменять мир, но хочет изменить отношение к нему. Рассматривая тождественность двух базовых понятий Востока: «Атман есть Брахман» («Я сам есть единое и единственное божество » и «Брахман есть Атман» («мое высшее Я, от всего отрешенное, будет истинной, высшей, последней реальностью»), Б. П. Вышеславцев приходит к выводу, что первое ведет к теософскому пантеизму, а второе - к «антропософскому» атеизму (Вышеславцев, 1955: 157-158). Эти крайние решения могут истолковывать духовный опыт нирваны и как атеистическое затухание сознания, и как пантеистическое растворение в абсолютном. Аоктринальная концепция буддизма претендует, таким образом, на транскультурный, трансрелигиозный, транссистемный статус (Мертон, 1996: 199).

В XX в. буддистские мыслители привносят в западную культуру понимание того, что в буддизме очень сильна компонента индивидуального духовно-мистического опыта, которой не знает западное христианство (за редким исключением, например, М. Экхарта и Я. Беме). Именно эта интуитивная компонента, которая на самом деле изначально присутствует во всех мировых религиях (в буддизме - дзэн, в исламе - суфизм, в православном христианстве - исихазм), может стать в наши дни базой синтетического обновления культуры.

В данной статье мы рассмотрим современные холистические концепции, возникшие на основе кардинально противоположных религиозных моделей - синергийной антропологии как попытки расширения и осмысления духовной практики исихазма (С. С. Хоружий) и концепции интегральной духовности на основе Азэн-буддизма (К. Уилбер). Связующим звеном нашего анализа является проекция двух представленных парадигм через призму СТ, которое обладает потенциалом соединения современности с прошлыми и будущими поколениями, многоликостью возможностей духовного синтеза как творчества культуры, творчества жизни и творчества себя.

\section{БАЗОВЫЕ КОНЦЕПТЫ СИНЕРГИЙНОЙ АНТРОПОАОГИИ И КОНЦЕПЦИИ ИНТЕГРААЬНОЙ АУХОВНОСТИ}

Концепция синергийной антропологии. Это современное направление русской философии отражает ее общую историческую нацеленность: она «больше всего занята темой о человеке, о его судьбе и путях, о смысле и целях истории» (Зеньковский, 1991: 16; курсив наш. - А. Г., Т. Г.). Конструктивной предпосылкой такой антропологии является рассмотрение предельного духовного опыта индивида, который возникает в результате его открытости метаантропологическому телосу. Создатель данного направления, современный религиозный философ С. С. Хору- 
жий, выделяет две известные перспективы такой открытости, которые он называет «онтологической бифуркацией», - «...иичностная репрезентация онтологического Иного, Бог Аичность (в “религиях Аичности” - христианстве, исламе) и имперсональный Абсолют (Пустота, лежащая за пределами оппозиции бытия и небытия в восточных “религиях Космоса”)» (Хоружий, 2010: 628).

Наиболее важным понятием христианства, которое пришло вместе с ним, можно считать понятие «дух». Символической точкой отсчета духовного измерения в европейской культуре можно считать перевод слова «дух» с древнееврейского на древнегреческий христианскими апостолами: «Бог есть пневма» (Ев. Иоанна. IV, 24) и «Господь есть пневма» (2 посл. коринф. ап. Павла. III, 17) (Иосев, 1994: 301). Первоначальный древнегреческий смысл этого слова — «дуновение» расширяется до «дыхание», а у стоиков обретает универсальное и духовное значение. Если языческая пневма всегда оставалась в рамках чувственно-материального мира, то уже в раннем христианстве ее «стали понимать как такую личность, которая выше всякого чувственно-материального космоса, нисколько в нем не нуждается и от него не зависит, а, наоборот, является его создателем, его творцом» (там же: 300).

Вторым, связанным с духом, в византийском христианстве становится понятие «энергия» (energeia), которое первоначально использовал Аристотель, вводя его в триаду осуществления: «Возможность - Энергия (деятельность, действие) - Энтелехия (осуществленность, действительность)», единство которых приводит к событию. «...Возможность же переходит в действительность - ведь движение есть незавершенная действительность способного к движению [тела]» (Физика, 257b 5) (Аристотель, 1981: 238). И несколько иначе: «Ибо дело - цель, а деятельность дело, почему и “деятельность" (energeia) производно от “дела" (ergon) и нацелена на “осуществленность" (entelecheia)» (Метафизика, 1050a 20) (Аристотель, 1976: 246). Энергия как деятельность осуществляет действительность. Как промежуточное звено она может быть ближе либо возможности, либо осуществлению. Как отмечает С. С. Хоружий, «понятие энергии присутствует лишь в 2 областях - исихастском богословии и современной физике, которые отражают крайние, предельные формы опыта доступной человеку внутренней и внешней реальности» (Хоружий, 2000: 274). Современные вариации этого понятия типа «человеческая энергия», «психическая энергия» и т. п. на самом деле являются лишь условным наименованием некоторой реальности, которая оказалась вне поля рефлексии западной философии.

Понятие «энергия» входит в православную доктрину через труды св. Григория Паламы в XIV в., в эпоху исихастского Возрождения. Религиозное Возрождение в виде старчества в России происходит в XIX в. после осмысления переведенного на русский язык православного памятника - пятитомника «Аобротолюбие». Элементы исихастского опыта обнаруживаются и в более ранних практиках православия, например, у Сергия Радонежского. Концепция әнергийности оказывается плодотворной для православия, особым образом раскрывая его внутреннюю природу. Природа человеческой активности - телесной, душевной и духовной - стала пониматься как взаимодействие и взаимопроникновение различных энергий, причем божественная благодать тоже имеет, хотя и более высокую, но энергийную природу, которая «нисходит до человека». И хотя сущность Бога остается непознаваемой, в энергийной сфере осуществляется соединение человека с Богом, обожение (там же: 26). 
Понятие энергии позволяет представить духовный процесс как повышение организации человеческих энергий на пути к Богу, причем на высших ступенях восхождения в результате синергии открывается доступ к благодатным божественным энергиям. Синергия имеет несколько планов, кроме энергетического. В онтологическом смысле преодоление разрыва между Богом и устремлением человека, соединение двух несоизмеримых энергий осуществляется за счет «онтологического размыкания» - усиления и расширения индивидуального самосознания, выход за рамки «Я», превосхождение человеком тварной природы, из которого возникает сфера «личностного бытия-общения» с Богом (Хоружий, 2010: 627). Такая возможность синергии возникает (для христианина) в результате подвига Христа, сына Божия и человека, который перед лицом смерти подчинил себя и согласовал свою волю с волей Бога-отца.

Гносеологической составляющей синергии является момент «соработничества»- согласного действия свободной воли человека и божественной благодати: «У человека два крыла, чтобы возлетать к Богу: свобода и благодать» (Максим Исповедник, цит. по: Хоружий, 1998: 129). Об этом же ранее у Ап. Павла: «Мы соработники Бога» (1 Корин. 3, 9). Преображение сознания, которое возникает в «эмпирическом» процессе духовной практики (Праксис), становится основанием иного миропонимания - Феории: «исследующий и исполняющий Божью волю [есть] истинный философ, у которого мысль действенна, а действие осмысленно» (Св. Григорий Палама, 1995: 122). Радикальная перемена сознания (и самосознания) заключается в том, чтобы «войти в соединение с Богом, стать дичностью тварной с двумя природами: природой человеческой, обоженной, и природой или вернее, энергией Божественной - обожающей» (Иосский, 2012: 82). При этом «Петр остается Петром, Павел - Павлом, Филипп - Филиппом; каждый, преисполнившись Аухом, пребывает в собственном своем естестве и существе. А если утверждаешь, что естество разрушилось, то нет уже Петра или Павла, но во всем и повсюду - Бог, и отходящие в геенну не чувствуют наказания, а идущие в царство благодеяния» (Св. Макарий Великий, 2010: 214-215).

В социальном контексте духовно свободный человек должен и может прилагать эту свободу к делу создания духовного общества, поскольку может стать проводником социализации иного типа: «Святые столпники неподвижным подвигом двигают народные массы, и темные пещеры отшельников светят всему миру» (Соловьев, 1893: 41).

В культурном смысле исихастский опыт выступает как творчество второго порядка - «творение способности к творчеству себя». Максималистский религиозный идеал - обожение - предстает как «собранность» отдельной жизни - ее смысла, цели и финала, как «собранный дух» (Н. А. Бердяев). Это дерзновенная попытка эксперимента над собой, которая показывает путь восхождения по лестнице обретения смысла жизни и результаты которой становятся достоянием современников и потомков.

Таким образом, синтез понимания человека, осуществляемый синергийной антропологией на основе предельного антропологического опыта духовных практик, показывает максимально широкий диапазон творчества себя, СТ. Отказ от духовной составляющей в современном обществе делает востребованными другие антропологические типы. По мнению Хоружего, это Человек Онтический, повернувшийся к паттернам бессознательного, доминирующий с начала XX в. тип (другие его «имена» - массовый, одномерный, потребляющий и т. п.). Еще один ныне возника- 
ющий тип - Человек Виртуальный, обитатель информационного общества, развивает новые тренды размыкания тоже за пределы антропологической реальности, но не в сферу духа, а в сферу технологий - к мутантам и киборгам.

Концепция интегральной Ауховности. Самым общим понятием интегральной концепции американского философа и буддолога К. Уилбера является Космос, не физический космос, а духовный процесс во всех измерениях бытия, который «содержит в себе космос (или физиосферу), биос (или биосферу), психику, или разум (ноосферу) и теос (теосферу, или измерение божественного)» (Уилбер, 2019: 55). Понятие «Космология» в этой концепции отражает развертывание эволюции в физическом, биологическом, разумном, духовном (божественном) измерениях (Уилбер, 2020).

Вторым базовым понятием является идея о том, что Космос состоит из холонов (термин А. Кёстлера), которые, по определению, одновременно являются целым и частью чего-то другого (атом - часть молекулы, молекула - составная часть клетки, клетка - организма и т. А.). От аналогичного понятия «система», широко применяемого в науке, холон отличается своей «идеальной» природой. Будучи целым, холон обладает идентичностью, автономией и собственной деятельностью, но как часть должен быть в сообщности с другими частями. Это «горизонтальный» уровень его проявления, в «вертикальном» плане он способен к самотрансценденции (переход на более высокий уровень) или саморастворению (Уилбер, 2019: 61). Способность к трансценденции порождает «единую песню» Космоса - творческую эволюцию. Новые холоны - результат новизны, рождающейся в квантовых скачках творческих возникновений. Творчество - «еще одно имя Ауха», или Пустоты (там же: 63).

Третье базовое понятие - холархия - отражает иерархичность Космоса: «целое больше, чем сумма его частей» (там же: 66). Положение на более высоком уровне холархии означает и более глубокий уровень организации. Принцип холархии означает также, что разрушение более низкого уровня грозит уничтожением более высокому: если уничтожить жизнь на Земле, физиосфера останется, однако уничтожение физического космоса грозит гибелью живому. Точно так же ноосфера, включающая в себя биосферу как часть, будет уничтожена с гибелью биосферы.

«Аух - и самый высокий “уровень” в холархии, и та бумага, на которой написан план холархии. Это самая высокая ступень лестницы, но также и древесина, из которой лестница сделана. Аух является и Целью, и Основанием всей последовательности» (там же: 77). Он же определяет и тенденцию эволюции - возрастание сложности, дифференциации/интеграции, возрастание организации/структуризации, относительной автономии и телоса (там же: 80). Сознание есть то, «как глубина выглядит изнутри», поэтому «глубина вездесуща, сознание вездесуще и Аух вездесущ» (там же: 81). Великую холархию Космоса Уилбер разделяет на «четыре угла», типа, квадранта: внутренний индивидуальный (интенциональный — «Я»), внешний индивидуальный (поведенческий - «Оно»), внутренний коллективный (культурный - «Мы») и внешний коллективный (социальный — «Они»). «Углы» связаны между собой и присутствуют в каждом холоне подобно алмазу с четырьмя гранями (там же: 126). В каждом «углу» отмечаются свои специфические стадии эволюции, и в то же время они взаимодействуют между собой, образуя некую сеть. «Более высокие, или глубокие, стадии развития сознания раскрывают более глубокие и широкие паттерны в самости, индивидуальном поведении, культуре и общест- 
ве в интенциональном, поведенческом, культурном и социальном - во всех четырех квадрантах» (там же: 128).

Способы познания мира, которые Уилбер называет «двумя руками Бога», подразделяются на правосторонний (включающий квадранты «Оно» и «Они») и левосторонний (включающий квадранты «Я» и «Мы») пути. Принципиальная разница этих путей познания заключается в том, что правый основан на изучении внешних проявлений, поэтому он монологичен, т. е. относится к миру как к объекту, в котором интересны формы, а сам подход - позитивистский. Аевосторонний основан на интерпретации паттернов сознания, на герменевтике и понимании. Оба пути необходимы, равновесны, и в этом смысле они - «две руки».

В свете сказанного интегральная концепция предстает как вариант объективно$2 о$ идеализма, построенного на буддистской картине мира с добавлением и интерпретацией на основе современных научных открытий: «Концепция Болышого взрыва сделала идеалистами практически всех, кто может мыслить. Сначала было ничто, а затем “бам!” - и что-то возникло» (там же: 63). В ракурсе этого подхода «онтогенетическая» эволюция человека предстает как закономерная часть «филогенеза» Космоса.

\section{АУХОВНЫЕ МАРШРУТЫ ИНАИВИАА С ПОЗИЦИИ}

\section{СИНЕРГИЙНОЙ АНТРОПОАОГИИ И ИНТЕГРААЬНОЙ АУХОВНОСТИ}

Отличия «Ауховного упражнения» от Ауховной практики. Аоктринальные положения и синергийной антропологии, и интегральной концепции следуют из «эмпирического» опыта духовных практик, время отсчета которых - начало I тысячелетия н. э. Они возникла независимо друг от друга, но имеют явные черты сходства между собой и отличаются от античных духовных упражнений. Сходство духовного упражнения и практики в том, что оба представляют собой динамические и процессуальные стратегии самореализации. В парадигме духовных упражнений присутствует момент воспитания: реализация человечности, его изначальности как истинной природы, отсечение «дикой части души» (Платон). Но в отличие от духовной практики они не предполагают фундаментальной онтологической трансформации души (Хоружий, 2010: 455-456).

Можно назвать несколько черт, которые отличают духовную практику как от античных упражнений, так и от современных разного рода психологических практик и тренингов: 1) это целостная практика самоизменения за счет соединения (синергии) конфигураций человеческих энергий с внешними энергиями; 2) практика имеет поступательный характер, в котором можно выделить несколько дискретных состояний - ступеней продвижения к «высшему духовному состоянию», телосу; 3) во всех практиках существуют три уровня лестницы духа: низшие ступени - аскезы, душевного отрешения и духовной решимости, средние ступени - практики молитвы или медитации, создающие механизм восхождения, и высшая часть, проявляющаяся как выход за пределы «Я». Момент различения типов практик в двух рассматриваемых здесь доктринах возникает в точке выбора телоса: онтологический горизонт, соответствующий рождению личного бытия (исихазм) или бытия безличного, ведущего к деконструкции человека (классическая йога, тибетский тантрический буддизм, дзэн, даосизм).

«Крутой духовный поворот» в практиках начинается с отталкивания, ухода, т. е. с полного отвержения предыдущего способа бытия. Сам процесс практики представляет собой строго обозначенный уникальный способ продвижения к опреде- 
ленной цели. Конечный результат - достижение онтологической трансформации - требует участия вне- и сверхприродных факторов (Внеположный Исток, согласно С. С. Хоружему), которыми человек не управляет в силу их спонтанности.

Ауховная практика исихазма как восхождение по Иестнице духа. Исихастская практика в отличие от всех практик обыденного существования «является не только антропологической практикой, но имеет метаантропологическое измерение: она строго целенаправленна, но ее цель не локализована нигде в горизонте эмпирического бытия (не-наличная цель, «транс-цель», Телос)» (там же: 603). Возникающая на основе этой практики доктрина пытается преодолеть ее субъективность через выделение универсальных состояний и переживаний. Так возникают ступени восхождения: покаяние (перемена ума) и обращение - борьба со страстями исихия - сведение ума 8 сердие - непрестанная молитва - бесстрастие - чистая молитва - обожение (Хоружий, 2000: 241). Эта последовательность описывает, говоря современным языком, методологические этапы динамики духовного процесса.

Покаяние (греч. «метанойя» - перемена) в исихазме означает полную перестройку как внутренней, так и поведенческой стратегии и совершается за счет достаточно экстремальных и болезненных практик, «покаянных трудов» аскезы, самоосуждения, скорби и т. п. Начиная с покаяния, практика создает несколько ступеней антиномичной неравновесности, аналогичной тому, что описывается синергетикой: переходу к следующей ступени, предшествует процесс «раскачки» системы, затем резкий разрыв, скачок и выход к новому уровню. Антиномичность «острое покаяние - самонаблюдение» в начальной фазе пути - перехода от «ветхого» человека к новому - выступает как внутренняя динамическая неравновесность, вводящая человека в творческое состояние самопреобразования (Хоружий, 1998: 91). Процесс восхождения задается особой функцией человеческого сознания - верой, которая формирует цель и создает условия для объединения разума и чувства для ее достижения: «Вера есть раскрытие в своем “я" иного, божественного, выход из “я” и отдавание себя высшему <...> В акте веры, в волевой решимости верить человек всегда стоит на краю бездны» (Бердяев, 1989а: 56, 52).

Исихия (спокойствие, молчание, уединение, тишина) рождается как результат борьбы со страстями, как смиренномудрие, мир после шума и битвы из антиномии «слово - молчание». «Сведение ума в сердце» (трезвение) означает преодоление «рассеянности» обычного человека, которая возникает из разделенности функций ума и души («сердца»): «...на сердце набегают заботы и страсти, а ум, занятый внешним миром, рассеивается и дробится» (Хоружий, 1998: 105). В состоянии «умо-сердце» создается «единый экзистенциально-энергийный орган человеческого существа», фокус, где сходятся все его энергии. Непрестанная молитва как способ внутренней концентрации внимания должна стать такой, чтобы «умно зреть перед собой присущего невидимого Бога» (там же: 109). Соединение непрестанной молитвы и внимания создает антропологический механизм, «онтологический движитель», который служит ключом к синергии неоднородных энергий - человеческой и божественной. Бесстрастие преодолевает антиномию «очищение сердца от страстей - концентрация всех страстей» в любви к Богу: «...опыт бесстрастия... положительного, которое проявляется как полновластие любви Божией» (там же: 137). Чистая молитва, «неизглаголенная молитва» - преображенное состояние изумления и созерцания нетварного света. Бог есть дух, свет, поэтому путь к нему - через свет, но этот свет не интеллектуальный и чувственный, вне прост- 
ранства и времени, он одновременно энергия и благодать. Обожение есть кульминация человеческого устремления и Божьей благодати, отражение в человеке синергии человеческих и божественной энергий, что у Ап. Павла (Гал. 2, 20) звучит так: «Уже не я живу, а живет во мне Христос». Это момент рождения Аичности, которая в православии «отождествляется с Божественной Ипостасью... тогда как әмпирический человек не рассматривается как личность» (Хоружий, 2016: 27).

Исихастская лестнича восхождения фиксирует действия и устремления идущего по ней, но достигаемые состояния невыразимы словами, приходят одновременно и изнутри человеческого "S》, и снаружи, точнее - как бы свыше, и переживаются субъективно как абсолютная новизна. Предельная антиномия исихастской практики лежит в диапазоне между требованиями точности аскетической техники и спонтанности ( «самодвижности») энергетических переходов, наводимых синергией с божественной энергией. В моменты переходов, названных синергетикой «точками бифуркации», существует вероятность движения как вверх, так и вниз. Поэтому Аестница духа - лестница «без перил», когда возникший «внутренний эгоизм фарисейской самоправедности» (Феофан Затворник, цит. по: Хоружий, 1998: 235), как известно из Библии, может способствовать падению даже ангела.

Предельный опыт СТ в исихазме как бы задает вопрос: «А где твое место на этой лестнице?» Атеист и скептик может заметить, что все эти состояния - игры разума и воображения, и не стоит ввергать одну-единственную жизнь в такие неопределенные эксперименты. Но нечто из глубины «Я» подсказывает современнику, что «вера, на которую люди боятся рискнуть, так как дорожат своей рассудочностью, ничего не отнимает, но все возвращает преображенным в свете божественного разума (Бердяев, 1989а: 68), а «тоска по Богу» становится лейтмотивом современной безысходности. Истинность исихастского опыта связана не с формально-логическими построениями, как в науке, а с глубоко личным онтологическим переживанием, благодатно даруемым.

Концепция интегральной духовности как холархия актуализации. Уилбер представляет реальность как Великую холархию бытия и сознания, состоящую из пяти сфер, которые последовательно восходят к более широким и, соответственно, более глубоким: материи $\rightarrow$ жизни (тела) $\rightarrow$ ума $\rightarrow$ души $\rightarrow$ духа (Уилбер, 2019: 75). Аевять базовых уровней сознания («вех») человека вписываются в них как подсферы: 1) сенсорно-физическая (сфера «материя»); 2) эмочионально-витальная (сфера «тело»); 3-6) разные уровни развития разума (сфера «ум»); 7) психическая, 8) тонкая (сфера «душа»); 9) причинная (сфера «дух»). Следующий уровень духа - недвойственный - не является сферой, но «предельным состоянием, итоговой конечной точкой для всего развития и эволюции... приравнивается к полному Просветлению, предельному высвобождению, чистой нирване» (там же: 288). «Самоощущение того, что вы есть Свидетель, “находящийся тут”, полностью исчезает, и Свидетель оказывается всем свидетельствуемым» (там же).

Начальные уровни сознания, вехи $1-3$, относятся к раннему детству и характеризуются соответственно как «вылупливание физической самости», «рождение эмоциональной самости» и «рождение концептуальной самости» (мира образов и понятий) (там же: 216, 218, 222), которые в «филогенетическом» смысле соответствуют архаическому, магическому и мифическому мировоззрению. Вехи 4-6 означают фундаментальную «смену парадигмы» - переход к рациональному мышлению разных стадий созревания, которое на визионерской стадии обретает способность синтезирующей логики ${ }^{1}$ (там же: 248). 
Как и исихазм, практики буддизма фиксируют выход за пределы самости, когда сознание «начинает разотождествляться с самим умом <... он (ум $-A . \Gamma$., $T$. Г.) начинает становиться объектом» (там же: 256 ; курсив источника $-A . \Gamma$., T. Г.). Вехи 7-9 - психическая, тонкая и причинная - становятся надличностными и обладают каждая своим типом мировоззрения. Природный мистицизм психической стадии ощущается как растворение «Я» в природе; божественный мистицизм тонкой стадии переживается как внутреннее озарение, во время которого каждый видит то, к чему был устремлен: христианин - Христа, буддист - Будду, юнгианец - архетипический опыт самости и т. п.; чистая Пустота, или бесформенный мистицизм причинной стадии, - это разотождествление со всеми, с любыми объектами и становление чистого наблюдающего Я, пребывание в бескрайнем просторе Свободы - в великом Нерожденном, безбрежной Пустоте (там же: 281, 284).

Уилбер отмечает, что понятие уровней и лестницы годится лишь как метафора, поскольку «каждая более высокая стадия в действительности не восседает на нижележащей стадии, а скорее обертыъает ее» (там же: 192; курсив источника А. Г., Т. Г.). В отличие от исихастской лестницы девять описыьваемых уровней сознания как бы объективированы: известны переживания, которые им сопутствуют, и сохраняется единственная техника их достижения - медитация как состояние рачионального постижения, которое заканчивается саморастворением. Если вернуться к базовым понятиям, то эта «лестница» интегральной духовности есть «Оно», «объективно» существующая иерархия, в которую отдельное сознание просто входит. «Взбирающийся», человеческая самость, отождествляется с этими ступенями, что порождает различные типы самоотождествления и различные типы развития «Я ». На каждом уровне сознание «взбирающегося» сначала внедряется, отождествляет себя с ним, затем превосходит его, трансцендирует, переходит на новый уровень и включает, интегрирует его в общий путь актуализации. С каждой ступени мир выглядит иначе, и меняются идентификация, потребности, мировоззрение и моральная позиция.

Таким образом, предельное состояние в восточных духовных практиках характеризуется не только безличностью, но и небытийностью. Поэтому на последних стадиях СТ превращается в свою противоположность - само-деконструкцию человека. В отличие от состояния благодати, которая не контролируется человеком, состояние «самадхи» на высших стадиях продвижения в дзэн-буддизме в принципе контролируется сознанием. Но и в дзэн присутствуют механизмы спонтанности, например, сатори ( «просветление») - это внезапный прорыв сознания, долго ощущающего себя в тупике, иногда на крайней грани отчаяния и бессилия, которое вдруг в результате внешнего воздействия (вмешательства Мастера, звука и т. п.) переходит в искомое состояние - нирваны, Великой Пустоты. Согласно Хоружему, «онтологическим движителем» в состоянии неравновесности выступает синергия, слияние с энергией Внеположного источника. Уилбер называет движителем универсальный «тайный импульс», который определяет в принципе всю эволюцию Космоса.

Основные отличия СТ в духовных практиках синергийной антропологии и концепции интегральной духовности можно свести к следующим.

1. Исихастское сознание проходит духовный процесс, который оно само строит, причем процесс идет за счет собственных энергий человека, которые подчиняются его воле, и спонтанных энергий, которые ощущаются как исходящие из Внеположного Источника. «Мистика обожения не есть мистика экстаза, медитации или со- 
зерцания, это акт претворения “тварной падшей природы” человека в природу Божественную» (Хоружий, 2000: 264), т. е. СТ в самом глубинном его проявлении. Напротив, буддистское сознание усиливает свой статус в результате общей тенденции творческой самотрансценденции, встроенной во Вселенную. И в этом смысле сознание человека не имеет особой привилегии, но находится на общей шкале возрастания организации, сложности и т. п.

2. Из двух практик рождается различное понимание духа и духовности. По Бердяеву, дух - это «свободная энергия, прорывающаяся в природный и исторический мир» (Бердяев, 1952: 157), и его рост осуществляется заключенной в человеке духовной силой. Исихасты прибавляли, что действие этой силы имеет божественную составляющую. Образование духовного центра «Я», подчиняющегося высшему смыслу, способствует выходу из поглощенности собой и точкой отсчета и условием реализации личности. Аух исходит из глубинного «Я» человека, синтезируя и поддерживая единство личности. Поэтому «человек должен все время совершать творческий акт в отношении к самому себе. В этом творческом акте происходит самосозидание личности» (там же: 164), а духовность предстает как богочеловеческое состояние, через которое утверждаются личность, свобода и любовь.

Согласно же Азэн, дух есть в человеке, как и в других холонах, поскольку человек - часть Космоса. И в силу закона Великой холархии его духу также присуща внутренняя чистота и праведность, как всему Космосу (Судзуки, 1996: 158).

3. СТ в восточном христианстве - это «горячий» путь, преобразование разрозненных личных чувств в страстную силу души, устремленную к Богу: «Старайтесь иметь возгретым какое-либо чувство к Богу - страха, Аюбви, упования... Се норма внутреннего строя» (Феофан Затворник, цит. по: Хоружий, 2000: 233). Эта «норма внутреннего строя» возникает из опыта смиренномудрия и бесстрастия - к себе, окружающим, событиям мира, «саморазогрев» которой возникает каждый раз спонтанно в направлении ясно ощущаемого телоса. СТ в буддизме - это «холодный» путь рационального осознания положения «Я»на ступенях переходов, особенно на этапе выхода в пространство сверхсознания, выхода за границы «Я»: «Это Ауша, встретившаяся лицом к лицу с бытием <...> Аля которой личностное потеряло глубину» (Уилбер, 2019: 234). Здесь, напротив, созерцание и медитативные техники, изгоняя эмоции, делают это как бы навсегда, охлаждая внутреннюю реальность и деконструируя все персоналистическое.

4. Исихаст творит новизну, создает ее как первозданность, своим «соработничеством» с божественной энергией строит сферу духа (пневматосферу), которую без него никто не создаст. Азэн-буддист вступает в божественное пространство (теосферу), которое было «заготовлено» до него. Концепция интегральной духовности претендует на предельное обобщение: конечное предстояние перед Богом (присущее христианству) трактуется в ней как состояние лишь определенного уровня перехода, «тонкого» сознания, находящегося на выходе из сферы души. А дзэн, провозглашающий себя сущностью буддизма, «на самом деле является духом всех религий и философий» (Судзуки, 1996: 164). Поэтому «христиане могут заниматься дзэн наряду с буддистами точно так же, как большая рыба и маленькая рыбешка мирно уживаются в одном и том же океане» (там же: 164-165). На наш взгляд, эта уверенность не оправданна, так как христианский путь - молитвенный, требующий внутреннего диалога с Богом.

5. Обе духовные практики на определенной ступени свидетельствуют о выходе за рамки «Я». При этом мир восточного христианства требует «размыкания навстре- 
чу личному самобытию», создания иного образа самобытия - Аичности, структура которой позволяет ей предстать перед Божьим Аиком. Азэн называет «ваше Изначальное лицо... чистейшей пустотой, или прозрачностью, этого мерцающего мира явлений» (Уилбер, 2019: 292).

Оба подхода являются холистическими концепциями, в которых духовная практика, направленная к определенному телосу, определяет рациональные способы ее

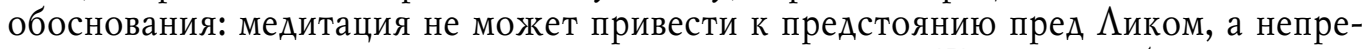
рывная молитва не может закончиться «растворением». Поэтому выбор стратегии духовной практики полностью предопределяет перспективы ее результата. Указанные духовные комплексы создавались в течение столетий, и каждый из них к настоящему времени предстает как «органон духовного опыта», в котором представлен «полный свод правил его подготовки, организации и интерпретации» (Хоружий, 2016: 248). Ауховная практика имеет две ярко выраженные ступени выбора: на первой ступени это протест против повседневности, «поворот-к-себе», выбор в пользу «вопрошания бытия» (М. Хайдеггер), на второй ступени это выбор стратегии «обрашения». И здесь дороги расходятся. В иудаизме, христианстве и исламе это «обращение к Богу» ( «размыкание себя» божественной энергии) и формирование Аичности, предстоящей перед Ним. «Обращение-к-Пустоте (Единому)» в восточной парадигме духовных практик, напротив, ведет к растворению персоналистических структур.

\section{ЗАКАЮЧЕНИЕ}

Осмысление представленных духовных практик фиксирует их различия. Из восточно-христианской практики духовного восхождения рождается русская религиозная философия, которая сама себя назвала «философией сердца». Словосочетание «философия сердца» впервые употребил Б. П. Вышеславцев в работе «Сердце в христианской и индийской мистике» (1929). Русский философ определяет сердце как производное от славянского «сердо»- средоточие телесное, душевное и духовное, которое удерживает его целостность. Оно «есть орган, устанавливающий эту особую интимную связь с Богом и ближним, которая называется христианской любовью» (Вышеславцев, 1955: 52). Исихастская ступень выхода за рамки «Я»«сведение ума в сердце»- - ает оправданное, практическое основание для синтеза разума и чувства в философии сердца, которая возлагает на человека всю ответственность перед Богом, миром и Аругим: «Человек-микрокосм ответственен за весь строй природы, и то, что в нем совершается, отпечатывается на всей природе» (Бердяев, 1989b: 305-306). Философия сердца - это и предостережение миру: «Современное человечество... должно понять и убедиться, что... культура без сердца есть не культура, а дурная “цивилизация”, создающая гибельную технику и унизительную мучительную жизнь» (Ильин, 1993: 296). Аолжен родиться новый облик философии человека, базирующейся на «онтологической открытости - расширенном и динамическом видении феномена человека» (Хоружий, 2000: 264).

Пантеизм, внутренняя неопределенность и широта трактовок делают восточные «религии Космоса» универсальным базисом для создания философских систем наподобие объективного идеализма. Уилбер, автор концепции интегральной духовности, критикуя западную установку на объективацию и называя ее «поверхностью» и «монологизмом», не замечает, что сам создает такую же, заменяя материальную реальность идеальной конструкцией «недвойственности», в которой удел человека - «уходить». В интегральной картине мира представлено то, 
что можно назвать «оптимистическим сценарием исчезновения» как закономерным процессом, предопределенным Космосом, к которому человечество постепенно подходит. Наиболее значимые концепции постмодернизма - постистории и симуляционной реальности (Ж. Бодрийар), власти-знания (М. Фуко), искусства как копии (У. Эко), ризоматичности (Ж. Аелез, Ф. Гваттари) - также фиксируют исчезновение - Субъекта, Автора и Читателя, которые выступают не столько как творцы (или со-творцы) культуры, сколько как комбинаторы отдельных элементов.

«Разбожествление» мира, начавшееся в западной культуре конца XVIII в., прошло несколько стадий: «преодоление понимания Бога как личности в представлении о божественности, замена принципа абсолюта принципом плюральности, трансцендентного измерения Бога - имманентным» (Ростова, 2017: 281). Авижение в сторону автономии человека «поочередно вытесняло Бога из политики, из нравственности, из искусства и познания» (там же: 309). Но наступившее «совершеннолетие» невозможно отождествить со здоровьем человечества. «Бог умер», и вместе с ним исчезло то пространство человеческого, что и делает человека человеком. Телесно живущий все дольше, человек теперь болен духовно, болен тяжко и как-то беспросветно. «Мекарством» от духовных болезней в прошлом был «выход из повседневности», совершаемый, так сказать, элитарно, но на виду у всех. Ныне нет традиционных ниш для такого «выхода», есть только личный выбор СТ, который в социальном ракурсе предстает как исключение, жизненный эксперимент над собой. Утерявший Бога, но не потерявший желания верить, человек пытается противопоставить духовно бесплодному атеизму новые версии религиозности, из которых западному сознанию очевидны две - «религия без бога» (на основе буддизма) и беспредельный религиозный плюрализм (доходящий до принципа «создай себе личного бога»). Но существует предчувствие некоего нового пути, вехи которого осознаны в исихастской духовности. Его смысл - миссия к Предстоянию, его истина - Аюбовь, которая позволяет стать «горячим» в своем отношении к миру, его механизм - соединение человеческих энергий с энергией Божественной, его реализация - обращение к глубинной способности человека - «творчеству творчества», творчеству второго порядка, Самотворчеству. Это иной, не буддистский и не атеистический, сценарий развития мира, который обозначен русской философией сердца и исторически подтвержден практиками исихазма и старчества.

\section{ПРИМЕЧАНИЕ}

1 Реп-ум - рождение понятийной самости, ум правила/роли (коноп) - осознание роли другого и приспособление к социальным ролям, формально-рефлексивная (формоп) - способность к формально-операционному сознанию, визионерско-логическая (кентавр) 一 интегрирующее сознание.

\section{СПИСОК АИТЕРАТУРЫ}

Аристотель (1976) Метафизика // Аристотель. Сочинения : в 4 т. / ред. В. Ф. Асмус. М. : Мысль. Т. 1.559 с. С. 65-368.

Аристотель (1981) Физика // Аристотель. Сочинения : в 4 т. / Вступ. ст. и примеч. И. А. Рожанский. М. : Мысль. Т. 3.613 с. С. 59-262.

Бердяев, Н. А. (1952) Экзистенциальная диалектика божественного и человеческого. Париж : YMCA-PRESS. 246 с. 
Бердяев, Н. А. (1989а) Философия свободы // Бердяев, Н. А. Философия свободы. Смысл творчества. М : Правда. 607 с. С. 14-253.

Бердяев, Н. А. (1989b) Смысл творчества // Бердяев, Н. А. Философия свободы. Смысл творчества. М : Правда. 607 с. С. 254-580.

Бернюкевич, Т. В. (2009) Буддизм в российской философской культуре. «Чужое» и «свое». М. : Книжный дом «Ииброком». 160 с.

Вышеславцев, Б. П. (1955) Вечное в русской философии. Нью-Йорк : Изд-во им. Чехова. 172 c.

Горелов, А. А., Горелова, Т. А. (2020а) Роль самотворчества в становлении индивидуальности в Античности: духовное упражнение «научиться жить»// Знание. Понимание. Умение. № 1. C. 54-72. DOI: 10.17805/zpu.2020.1.4.

Горелов, А. А., Горелова, Т. А. (2020b) Роль самотворчества в становлении индивидуальности в Античности: духовные упражнения «научиться общению с Аругим» и «научиться умирать»// Знание. Понимание. Умение. № 2. С. 68-83. DOI: 10.17805/zpu.2020.2.6.

Горелов, А. А., Горелова, Т. А. (2020c) Самотворчество как восхождение в «горний мир»: духовная практика Плотина // Знание. Понимание. Умение. № 3. С. 125-139. DOI:10.17805/ zpu.2020.3.10.

Зеньковский, В. В. (1991) История русской философии : в 2 т. Аенинград : Эго. Т. 1. Ч. 1. $221 \mathrm{c}$.

Ильин, И. А. (1993) Путь к очевидности. М. : Республика. 431 с.

Иосев, А. Ф. (1994) История античной эстетики: Итоги тысячелетнего развития : в 2 кн. М. : Искусство. Кн. 2. 604 с.

Аосский, В. (2012) Очерк мистического богословия Восточной церкви // Иосский, В. Очерк мистического богословия Восточной церкви. Аогматическое богословие / пер. с фр. В. А. Рещиковой. 2-е изд., испр. и перераб. СТС 1.586 с. С. 9-378.

Мертон, Т. (1996) Азэн и голодные птицы // Судзуки, А. Т. Мистицизм: христианский и буддистский. М. : ИА «София». 288 с. С. 193-274.

Ростова, Н. Н. (2017) Изгнание Бога. Проблема сакрального в философии человека : монография. М. : Проспект. 432 с.

Св. Григорий Палама (1995) Триады в защиту священно-безмолвствующих / послесл. и пер. В. Вениаминова. М. : Канон. 380 с.

Св. Макарий Великий (2010) Гл. 15. Будущая жизнь // Аобротолюбие : в 5 т. Изд. 4-е. / пер. с греч. свт. Феофана Затворника. М. : Изд-во Сретенского монастыря. Т. 1. 608 с.

Соловьев, В. С. (1883) Великий спор и христианская политика. М. : Тип. М. Н. Ааврова и К․ $260 \mathrm{c}$.

Судзуки, А. Т. (1996) Мистицизм: христианский и буддистский. М. : ИА «София». 288 с.

Хайдеггер, М. (1997) Бытие и время / пер. с нем. В. В. Бибихина ; ред. В. А. Айрапетян. М. : Ad Marginem. 452 c.

Хоружий, С. С. (1998) К феноменологии аскезы. М. : Изд-во гуманитарной литературы. $352 \mathrm{c}$.

Хоружий, С. С. (2000) О старом и новом. СПб. : Алетейя. 477 с.

Хоружий, С. С. (2010) Фонарь Аиогена. Критическая ретроспектива европейской антропологии. М. : Институт философии, теологии и истории св. Фомы. 688 с.

Хоружий, С. С. (2016) Социум и синергия: колонизация интерфейса. Казань : Казанский инновационный университет им. В. Г. Тимирясова. 452 с.

Уилбер, К. (2019) Краткая история всего / пер. с англ. Е. Пустошкина. М. : Манн, Иванов и Фербер. 448 с.

Уилбер, К. (2020) Интегральная духовность. Новая роль религии в современном и постсовременном мире / пер. Е. Пустошкина. М. : Манн, Иванов и Фербер. 384 с. 


\title{
RELIGIOUS ASPECTS OF THE MODERN PARADIGM OF SELF-CREATION
}

\author{
A. A. GORELOV \\ RAS INSTITUTE OF PHILOSOPHY, \\ T. A. GORELOVA \\ MOSCOW UNIVERSITY FOR THE HUMANITIES
}

The article deals with modern holistic concepts of self-creation (SC), which arose on the basis of radically opposite religious models - synergetic anthropology as an attempt to expand and comprehend the spiritual practice of hesychasm (S. S. Khoruzhiy) and the concept of integral spirituality based on Zen Buddhism (K. Wilber). The basic concepts of both points of view are presented: spirit, energy, synergy - in synergistic anthropology; Cosmos, holon, holarchy - in the concept of integral spirituality. SC, represented as climbing up the Ladder of Spirit on the basis of the spiritual practice of hesychasm - is a daring attempt to experiment on oneself, which shows the way to gain the meaning of life. The doctrine that emerges from this practice attempts to overcome its subjectivity by highlighting universal states and experiences: the meaning of life is a mission to the Future, the truth is Love, which allows you to become "hot" in your attitude to the world, the mechanism is the connection of human energies with Divine energy, the realization is an appeal to the deep human ability - "creativity of creativity", creativity of the second order, Self-creation.

The concept of integral spirituality presents SC as a holarchy of actualization that passes through the nine basic levels of human consciousness and eventually comes to impersonality and non-existence, turning into its opposite - the self-deconstruction of man. The main differences between SC in the two types of spiritual practices are discussed in detail.

Keywords: self-creation; spirituality; synergy; holarchy; Orthodoxy; hesychasm; Zen Buddhism; S. S. Khoruzhiy; K. Wilber

\section{REFERENCES}

Aristotle (1976) Metaphysics. In: Sobranie sochinenii : in 4 vol. Vol. 4. / ed. by V. F. Asmus. Moscow, Mysl'. 559 p. Pp. 65-368. (In Russ.).

Aristotle (1981) Physics. In: Sobranie sochinenii : in 4 vol. Vol. 3 / Intr. article and notes by I. D. Rozhansky. Moscow, Mysl'. 613 p. P. 59-262. (In Russ.).

Berdyaev, N. A. (1952) Ebkzistencialnaya dialektika bozbestvennogo I cbelovecheskogo. Paris, YMCA-PRESS. 246 p. (In Russ.).

Berdyaev, N. A. (1989a) Filosofiya svobody. In: Berdyaev, N. A. Filosofiya svobody. Smysl tvorchestva. Moscow, Pravda. 607 p. Pp. 14-253. (In Russ.).

Berdyaev, N. A. (1989b) Smysl tvorchestva. In: Berdyaev, N. A. Filosofiya svobody. Smysl tvorchestva. Moscow, Pravda. 607 p. Pp. 254-580. (In Russ.).

Bernyukevich, T. V. (2009) Buddizm v rossijskoj filosofskoj culture. "Chuzboe" I "svoe". Moscow, Book House "Librocom". 160 p. (In Russ.).

Vysheslavtsev, B. P. (1955) Vechnoe v russkoy filosofii. NY, Chekhov Publishing House. 172 p. (In Russ.).

Gorelov, A. A. and Gorelova, T. A. (2020a) Rol' samotvorchestva v stanovlenii individual'nosti v Antichnosti: duhovnoe uprazhnenie «nauchit'sja zhit'». Znanie. Ponimanie. Umenie. no. 1, pp. 54-72. DOI: $10.17805 /$ zpu.2020.1.4. (In Russ.).

Gorelov, A. A. and Gorelova, T. A. (2020b) Rol' samotvorchestva v stanovlenii individual'nosti v Antichnosti: duhovnye uprazhnenija «nauchit'sja obshheniju s Drugim» i «nauchit'sja umirat'». Znanie. Ponimanie. Umenie, no. 2, pp. 68-83. DOI: 10.17805/zpu.2020.2.6. (In Russ.).

Gorelov, A. A. and Gorelova, T. A. (2020c) Samotvorchestvo kak voskhozhdenie v gornij mir: duhovnaya praktika Plotina. Znanie. Ponimanie. Umenie, no. 3, pp. 125-139. DOI:10.17805/ zpu.2020.3.10. (In Russ.).

Zenkovsky, V. V. (1991) Istoriya russkoj filosofii: in 2 vols. Vol. 1. Part 1. Leningrad, Ego. 221 p. (In Russ.). 
Ilyin, I. A. (1993) Put k ocbevidnosti. Moscow, Respublika. 431 p. (In Russ.).

Losev, A. F. (1994) Istorija antichnoj jestetiki: Itogi tysjacheletnego razvitija. In 2 books. B. 2. Moscow, Iskusstvo. 604 p. (In Russ.).

Lossky, V. (2012) Ocherk misticheskogo bogosloviya vostochnoj cerkvi. In: Lossky, V. Ocherk misticheskogo bogosloviya vostochnoj cerkvi. Dogmaticheskoe bogoslovie / trans. from Fr. by V. A. Reschikova. 2nd ed. Holy Trinity Sergius Lavra. 586 p. Pp. 9-378. (In Russ.).

Rostova, N. N. (2017) Izgnanie Boga. Problema sakral'nogo v filosofii cheloveka. Moscow, Prospekt. 432 p. (In Russ.).

Merton, T. (1996) Dzehn I golodnye pticy. In: Suzuki, D. T. Misticizm: bristianskij I buddistskij. Moscow, Sofia. 288 p. Pp. 193-274. (In Russ.).

St. Gregory Palamas (1995) Triady v zashchitu svyashchenno-bezmolvstvuyushchib [Translation]/ afterword and transl. by V. Veniaminov. Moscow, Canon. 380 p. (In Russ.).

St. Macarius the Great (2010) Chapter 15. Budushchaya zhizn. In: Dobrotolyubie : in 5 vols. $4^{\text {th }}$ ed. / transl. from Greek by Theophan the Recluse. Vol. 1. Moscow, Publishing house of the Sretensky monastery. 608 p. (In Russ.).

Solovyov, V. S. (1883) Velikij spor I bristianskaya politika. Moscow, Printing house of M. N. Lavrov and Co. 260 p. (In Russ.).

Suzuki, D. T. (1996) Misticizm: bristianskij I buddistskij. Moscow, Sofia. 288 p. Pp. 7-192. (In Russ.).

Heidegger, M. (1997) Bytie I vremya. / transl. from German by V. V. Bibihin; ed. by V. A. Ajrapetyan. Moscow, Ad Marginem. 452 p. (In Russ.).

Horuzhij, S. S. (1998) K phenomenologii askezy. Moscow, Publishing House of Humanitarian literature. 352 p. (In Russ.).

Horuzhij, S. S. (2000) O starom I novom. Saint Petersburg, Aleteia. 477 p. (In Russ.).

Horuzhij, S. S. (2010) Fonar' Diogena. Kriticheskaia retrospektiva evropeiskoi antropologii. Moscow, Institute of Philosophy, Theology and History of St. Thomas. 688 p. (In Russ.).

Horuzhij, S. S. (2016) Socium i sinergija: kolonizacija interfejsa. Kazan, Kazan Innovative University named after V. G. Timiryasov. 452 p. (In Russ.).

Wilber, K. (2019) Kratkaya istoriya vsego / transl. from English by E. Pustoshkin. Moscow, Mann, Ivanov and Ferber. 448 p. (In Russ.).

Wilber, K. (2020) Integralnaya dubovnost. Novaya rol religii $v$ sovremennom I postsovremennom mire / transl. from English by E. Pustoshkin. Moscow, Mann, Ivanov and Ferber. 384 p. (In Russ.).

Submission date: 30.06.2021.

Горелов Анатолий Алексеевич - доктор философских наук, ведущий научный сотрудник Института философии РАН. Адрес: 119842, Россия, г. Москва, ул. Гончарная, А. 12. Тел.: +7 (495) 697-91-28. Эл. алpec: evolepis@iph.ras.ru

Горелова Татьяна Анатольевна - доктор философских наук, профессор кафедры философии, социологии и культурологии Московского гуманитарного университета. Адрес: 111395, Россия, г. Москва, ул. Юности, д. 5. Тел.: +7 (499) 374-55-11. Эл. адрес: fylosofy@mosgu.ru

Gorelov Anatoly Alekseyevich, Doctor of Philosophy, Leading Research Fellow, Institute of Philosophy, Russian Academy of Sciences. Postal address: 12, Goncharnaya St., Moscow, Russian Federation, 119842. Tel.:+7 (495)697-91-28.E-mail: evolepis@iph.ras.ru

Gorelova Tatyana Anatolyevna, Doctor of Philosophy, Professor, Department of Philosophy, Sociology and Culturology, Moscow University for the Humanities. Postal address: 5, Yunosti St., Moscow, Russian Federation, 111395. Tel.: +7 (499) 374-55-11. E-mail: fylosofy@mosgu.ru 